\title{
A DIMENSÃO DAS IMAGENS NA NARRATIVA DE BAÚ DE OSSOS, PRIMEIRO LIVRO DE MEMÓRIAS DE PEDRO NAVA
}

Bárbara Del Rio Araújo

Mestranda em Literatura Brasileira do Programa de Pós-Graduação em Estudos Literários /

UFMG (bolsista CAPES)

\section{RESUMO}

Este trabalho visa ao estudo da dimensão imagética em Baú de ossos. Busca-se verificar como as imagens do sujeito, de seus familiares e da sociedade brasileira são construídas na narrativa. Busca-se ainda notar a transfiguração desses âmbitos pela possibilidade de leituras imagísticas que relacionam analogicamente o eu e o mundo.

\section{Palavras-Chave}

Memória, imagem, Baú de ossos

\section{INTRODUÇÃO: BAÚ DO VIVIDO E DO IMAGINADO}

Baú de ossos (1972), primeiro dos seis volumes de memórias do escritor juiz-forano Pedro Nava, é caracterizado pela tradição literária como a obra do autor de maior requinte na fatura estética, já que nela se consegue empreender da história particular e do discurso autobiográfico dimensões mais alargadas. O livro de estreia, nesse sentido, "faz do chão da memória o espaço mais amplo e complexo das relações sociais e históricas”, ${ }^{1}$ possibilitando a transposição do universo individual para a história social.

Dotados de um enredo complexo, que suscitam inúmeras personagens, lugares e tempos ambivalentes, tanto o livro inicial do patrimônio memorialístico de Nava, Baú de ossos, quanto os demais, Balão cativo (1973), Chão-de-ferro (1976), Beira-mar (1978), Galo-das-trevas (1981) e

\footnotetext{
${ }^{1}$ ARIGUCCI JR. Enigma e comentário: ensaios sobre literatura e experiência, p. 78.
} 
Círio perfeito (1983) têm como matéria composicional as memórias do escritor, vividas sobretudo em Minas Gerais, Rio de Janeiro e Ceará; os documentos genealógicos, histórias e causos familiares; os ritos da tradição cultural e forte dose criativa, a qual se ocupa de rearranjar todo essa referencialidade.

A matéria do vivido se constitui matéria-prima para a narrativa, que remonta ao passado, aos espaços e às personae em um amálgama de documentos, retratos e impressões imaginativas. O sujeito Pedro Nava, seus familiares e o contexto social são reinventados em uma ambiguidade construtiva de realidade e ficção, memória e imaginação:

\begin{abstract}
Com a mão paciente vamos recompondo o puzzle de uma paisagem que é impossível completar porque as peças que faltam deixam buracos nos céus, hiatos nas águas, rombos nos sorrisos, furos nas silhuetas interrompidas e nos peitos que se abrem no vácuo - como vitrais furados (onde no burel de um santo vemos - lá fora! - céus profundos, árvores ramalhando ao vento, aviões, nuvens e aves fugindo), como aqueles recortes que suprimem os limites do real e do irreal nas telas oníricas de Salvador Dali. Um fato deixa entrever uma vida; uma palavra, um caráter. Mas que constância prodigiosa é preciso para semelhante recriação. E que experiência... A mesma que Cuvier partindo de um dente para construir a mandíbula inevitável, o crânio obrigatório, a coluna vertebral decorrente e osso por osso, o esqueleto da besta. A mesma do arqueólogo que da curva de um pedaço de jarro conclui de sua forma restante, de sua altura, de suas asas, que ele vai reconstruir em gesso para nele encastoar o pedaço de louça que o completa e nele se completa. ${ }^{2}$
\end{abstract}

Por meio de um discurso não uniforme, que relaciona recortes de depoimentos, documentos, retratos de pessoas reais, quadros e histórias familiares, o narrador parte em busca de seu passado como um homem que faz escavações: seu trabalho de memória é associado à atividade arqueológica, já que nela se fundamenta a relação crítica entre o objeto encontrado e o seu lugar de emergência. Nesse processo, nessa dupla instância, pode-se evidenciar a construção de uma imagem dialética, ${ }^{3}$ definida pela imagem produzida a partir de uma situação anacrônica em que se critica o objeto memorizado como representação acessível, visando o processo de perda e de sedimentação histórica do objeto no tempo. Trata-se de uma imagem, nos dizeres de Walter Benjamin, do "confronto entre tudo o que resta como indício do que foi perdido". 4

\footnotetext{
${ }^{2}$ NAVA. Baú de ossos: memórias, p. 41.

3 DIDI-HUBERMAN. O que vemos, o que nos olha, p.168. Em um capítulo específico, "A imagem crítica”, o autor contesta a tradição iconológica revelando a dimensão ambivalente, dialética, da imagem, a qual indica uma gama de complexidades sob a aparência das formas simples.

${ }^{4}$ BENJAMIN citado por DIDI-HUBERMAN. O que vemos, o que nos olha, p. 174.
} 
Em meio aos fragmentos e diante da certeza da impossibilidade de recuperação da memória na sua integralidade, cria-se, pelo designo do poético, verdades, tentativas inúmeras de representações daquele sujeito, daquela família e daquela sociedade em um processo que funde o registro documental e ficcional. A matéria do vivido é reescrita pelo poético, passando por um processo de estetização: os fatos reais transmudam-se. A narração se torna ela própria "uma terra que faz renascer os últimos restos, remanescentes e cacos de algo que estava irrecuperavelmente perdido e não podia mais ser recomposto por nenhum artifício do mundo”. 5 A memória é, pois, reconstruída e narrada por imagens e pelo investimento da escrita, que a reanima em um novo mundo.

Tendo em vista a perspectiva intervalar do passado memorialístico, os buracos da memória, a imaginação se revela como força plasmadora, que capta o esboço fugidio do passado, toda essa matéria difusa, e a organiza por meio de conjunções e disjunções imagéticas presentificadas. Por meio de analogias, em um jogo de relações, adivinhações, os retalhos do passado são suturados pela imaginação:

Os mortos... Suas casas mortas... Parece impossível sua evocação completa, porque de coisas e pessoas só ficam lembranças fragmentárias. Entretanto, podese tentar a recomposição de um grupo familiar desaparecido usando como material esse riso de filha que repete sorriso materno; essa entonação de voz que a neta recebeu da avó, a tradição que se prolonga no tempo a conversa de bocas há muito abafadas por um punhado de terra (...) esse jeito de ser hereditário que vemos nos vivos repetindo o retrato meio apagado dos parentes defuntos, o fascinante jogo da adivinhação dos traços destes pela manobra da exclusão(.... ${ }^{6}$

O simples fato de lembrar o passado, no presente, exclui a possibilidade de semelhança entre as imagens de um e de outro, "tudo é transfigurado, fazendo com que sua diferença se torne questão de ponto de vista”. 7 O registro documental, devassado pela recuperação imaginativa, habilita a construção não só da história particular de um homem, a imagem representativa do sujeito das memórias, mas também se torna porta para outras representações de grupos e do espaço social, que despontam na narrativa por meio de detalhes que unem elementos concretos com abstrações generalizadoras. O tratamento das memórias se aproxima, então, da ficcionalidade, fazendo com que, por um procedimento analógico, fatos singulares da esfera

\footnotetext{
${ }^{5}$ GUIMARAES. Imagens da memória: entre o legível e o visível, p. 150.

${ }^{6}$ NAVA. Baú de ossos: memórias, p. 40.

${ }^{7}$ BOSI. Memória e sociedade: lembrança de velhos, p. 17.
} 
íntima do narrador, ao serem evocados na composição narrativa, atuem como imãs a gerar inúmeras outras imagens e relações em uma dimensão mais universalizada. Dessa maneira, a partir do momento em que incorre o elemento imaginativo ao registro documental, acentua-se a universalidade desse registro que, a princípio, aborda o caráter particular, as memórias do indivíduo, mas que o generaliza em uma relação mais ampla. A imagem, portanto, que Pedro Nava constrói de si, no percurso autobiográfico de reconstrução de suas memórias, possibilita também ver como os familiares e a sociedade são representados, transluzindo um tipo de visão desse sujeito sobre o país. Trata-se, portanto, de apresentar as memórias como elas são construídas - documento e matéria criativa - em uma relação dialética entre o eu e o mundo:

\begin{abstract}
Nos seus livros, a autobiografia desliza para a biografia, que por sua vez, tem abertura para a história de grupos da qual emerge em plano mais largo a visão da sociedade, trazida finalmente em uma visão de mundo. O motivo dessa transfiguração do dado básico é sem dúvida o tratamento nitidamente ficcional que dá ares de invenção a realidade, transpondo para lá deles mesmo, o detalhe e o contingente, o individual e o particular. ${ }^{8}$
\end{abstract}

Nesse sentido, as representações da memória individual parecem existir quase estritamente em relação ao grupo e à sociedade: “O ritmo da narrativa obedece a uma superação constante do pormenor pessoal pelo andamento familiar e pela vida institucional ganhando, pois, o cunho de generalidade". ${ }^{9}$ A narrativa de Baú de ossos, pelo seu método de composição, que mescla o factual e o imaginário, traça, em uma dinâmica analógica, imagens das instâncias pessoal, familiar e social, saindo do âmbito particular para se enveredar a outros universos mais amplos como a "formação de uma família brasileira”:

Suprimindo a vaidade, o que procuro na genealogia, como biologista são as minhas razões de ser animais, reflexas, instintivas, genéticas, inevitáveis. Gosto de saber, na minha hora de bom ou mau, na de digno ou indigno, nobre ou ignóbil (...) - quem sou eu. (...) Poeticamente, a genealogia é oportunidade de exploração no tempo. Nada de novo sobre a face do corpo. Nem dentro dele. Esse riso, esse jeitão, esse cacoete (...) - são nossos e eternos, são deles e eternos. Vêm de trás, passam logo para o futuro e vão marcando uma longa cadeia de misérias. São sempre iguais e emergem ao lado das balizas trágicas do nascimento, do casamento, do amor, do ódio, da renúncia, da velhice e da morte. Vão pontuando e contrapontuando, um longo martírio... Meu, teu, seu, vosso, deles, delas. Eu, tu, ele, nós, vós, eles. Entre dois nadas, os pronomes dançam. Ah! dançam em vão... Assim como é, racialmente, minha gente, é o retrato da

\footnotetext{
${ }^{8}$ CANDIDO. Poesia e ficção na autobiografia[0], p. 61.

${ }^{9}$ CANDIDO. Poesia e ficção na autobiografia[0], p. 62.
} 
formação dos grupos familiares do país. Com todos os defeitos. Com todas as qualidades. Uns e outros, velhos, pois temos uma brasileirice de quinhentos anos, coeva do país, cada vez mais virulenta, pela sua passagem (uso o termo no sentido médico, laboratorial) numa série de homens e mulheres bons e maus, demônios ou quase santos (...) - família de várias cores com altos e baixos, com todas as fortunas. Nela tem sertanista preador e índio preado, negreiro e quem sabe? Negro também; conspiradores e delatores, oposicionistas cheio de brio e situacionistas sem vergonha, heróis e desertores, assassinos e vítimas - tudo entranhado na história do Brasil (...). Uma família como as outras, só que antiga. $^{10}$

O manejo com que a linguagem pictórica vai tratando de construir representações do narrador e também de sua família demonstra o encadeamento livre, solto, em que assunto-puxaassunto a formar uma cadeia de imagens e significados. Diante de um método de organização e montagem justapositiva, inferências particulares desdobram-se em novas emendas, marcando a heterogeneidade discursiva que tenta dar conta não só da reconstrução das memórias do indivíduo, mas do próprio real:

\begin{abstract}
A escrita segue o movimento volúvel da fala, por entre os detalhes, o assunto vai se formando, na medida em que ela se envereda por novos rumos e acaba se ramificando em contínuas enumerações sem aparentar outro esforço de estilo que não seja o de exprimir a mobilidade natural do pensamento no processo mesmo em que toma forma de linguagem. O resultado é uma prosa, ao mesmo tempo, abundante e solta, capaz de mover grandes massas com imponderável leveza. ${ }^{11}$
\end{abstract}

O estudo da relação entre memória e imaginação na narrativa de Baú de ossos permite, pois, compreender o processo de criação literária, o qual associa reciprocamente o campo estético aos fenômenos históricos sociais, impelindo em transfigurações e releituras. Nesse sentido, buscaremos verificar as técnicas de representação que parte de fragmentos memorialísticos e os transpõe, recriando-os pelo discurso ficcional. Sob a égide da dinâmica das imagens - do sujeito, da família e da própria sociedade -, investigaremos como se estabelece na narrativa um discurso tensional de reconstrução do eu, que permite deslizar por meio de analogias da representação autobiográfica para ramificações mais amplas, ilimitadas, de outros discursos, como, por exemplo, a genealogia familiar e a configuração da própria sociedade.

\title{
BAÚ DE OSSOS: A POÉTICA MODERNA DE RECRIAÇÃO DAS MEMÓRIAS
}

\footnotetext{
${ }^{10}$ NAVA. Baú de ossos: memórias, p 186.

${ }^{11}$ ARIGUCCI JR. Enigma e comentário: ensaios sobre literatura e experiência, p. 107.
} 
A obra de Pedro Nava, Baú de ossos, pode representar o paradoxo da obra de arte moderna, como nos fala Didi-Huberman nas suas considerações sobre a imagem crítica, na medida em que nela se constrói um espaço de negociação, de contradições, passado - presente e realidade - ficção. O processo de criação e representação estética das memórias de um sujeito representa, na concepção do crítico francês, a construção de uma imagem autêntica, marcada pela heterogeneidade:

A dimensão de uma obra de arte moderna não se deve nem a sua novidade absoluta (como se pudéssemos esquecer tudo) nem a sua pretensão de retornar as fontes (como se pudéssemos reproduzir tudo). Quando uma obra de arte consegue reconhecer o elemento memorativo do qual procede, para ultrapassálo, quando consegue reconhecer o elemento presente do qual participa para ultrapassá-lo, ela se torna uma imagem autêntica. ${ }^{12}$

Através de um discurso irônico, que engaja um sistema de releituras interpretativas dos fragmentos documentais, relatos genealógicos, os livros de Nava são compostos dentro de uma tradição moderna de autodrestruição criadora. Baú de ossos, por exemplo, não é a reprodução do passado do memorialista, mas a sua recriação, seu aproveitamento crítico, um discurso ampliado adensado de sentidos.

Em Poética do pós-modernismo, Linda Hutcheon explicita ainda melhor essa relação do discurso memorialístico com a poética moderna, na medida em que o caracteriza pelo estatuto ambíguo, o qual confronta paradoxos da representação fictícia e histórica, do particular e do geral, do passado e do presente. Para a autora, essa confrontação é, por si só, contraditória, pois se "recusa a recuperar ou desintegrar qualquer um dos lados da dicotomia e mesmo assim está mais do que disposta a explorar os dois pelo viés da intertextualidade parodística” ${ }^{13}$ Assim como Barthes $^{14}$, que diz ser impossível viver fora do texto e que este é por excelência um espaço social, em que nenhuma linguagem se exclui, ao contrário, se interage procurando não somente recuperar a história e a memória, mas também questionar a autoridade de qualquer ato de escrita, a autora toma a intertextualidade e a paródia como possibilidades de abertura dos textos para uma

\footnotetext{
${ }^{12}$ DIDI-HUBERMAN. O que vemos, o que nos olha, p. 193.

${ }^{13}$ HUTCHEON. Poéticas do pós-modernismo: história, teoria, ficção, p. 142.

${ }^{14}$ BARTHES. O óbvio e o obtuso. [0]
} 
abordagem de releituras críticas: “A paródia não é a destruição do passado, na verdade parodiar é sacralizar o passado e questioná-lo ao mesmo tempo.”15

Tem-se posto, portanto, a configuração da poética moderna como um ambiente crítico, interdiscursivo, hibrido, analógico por excelência, que coloca em diálogo elementos distintos. Nesse âmbito, o livro de memórias Baú de ossos se aproxima desse espaço, pois tem na sua facção e configuração a heterogeneidade temporal, discursiva, textual. O trabalho de Marlene de Paula Fraga, Da urdidura e da trama - um estudo sobre a intertextualidade de Pedro Nava (1995), reconhece, por exemplo, a tessitura das memórias como um mosaico, um jogo intertextual, que se vale de diversos planos - linguagens, momentos, tipos de texto - para reconstruir a cultura de uma época e de um lugar como também aponta para direções imprevisíveis, evidenciando um território aberto de signos e significações. Nesse sentido, valoriza-se a obra pelas técnicas de composição (analogia e ironia), que, através do par memória e imaginação, buscam relacionar criticamente os relatos, o passado memorialístico, os documentos, corroborando para a justaposição de múltiplas imagens e significados.

Na narrativa das memórias, o dado factual é interpelado por uma nova leitura, que “ultrapassa uma simples mímese figurativa para encaminhar-se a abstrações mais amplas”; ${ }^{16}$ o que faz surgir uma realidade nova. As imagens das pessoas, da família, do sujeito são representadas na narrativa como "crise e sintoma", 17 já que, ao mesmo tempo que pode fazer ressurgir o passado vivido, também pode transformá-lo, recriá-lo, tornando-o personagem de um novo mundo:

O processo de passagem, delicado e sutil, de um dado factual para a esfera lírica supõe uma afinidade profunda entre o poeta e o aspecto da realidade próxima a que se liga, para que se produza uma escolha tão significativa e ao mesmo tempo tão pessoal e íntima. Mas supõe também o reconhecimento da potencialidade literária da circunstância real, de onde se tira o elemento incorporado à construção poética. Isto, decerto, implica um modo de conceber a literatura que tende a ir além da mera escolha individual e é em parte determinado pelo momento histórico e pelos rumos gerais da produção literária do tempo. ${ }^{18}$

\footnotetext{
${ }^{15}$ HUTCHEON. Poéticas do pós-modernismo: história, teoria, ficção, p. 165.

${ }^{16}$ GUIMARAES. Imagens da memória: entre o legível e o visível, p. 189.

${ }^{17}$ DIDI-HUBERMAN. O que vemos, o que nos olha, p. 171.

${ }^{18}$ ARRIGUCCI Jr. Humildade, paixão e morte: a poesia de Manuel Bandeira, p. 52.
} 
Em uma articulação da experiência, do vivido, e da linguagem, ratifica-se o pressuposto da poética moderna da mistura discursiva. A memória, engenho poético, ativa a contradição dos tempos (presente e passado) e dos espaços (ficção e realidade). Essa faz surgir do presente o passado, além de trazer, no trabalho poético da experiência íntima, uma relação dialética entre o particular e o público, entre a experiência do eu e a do próximo. Os trechos que se seguem evidenciam como que na narrativa os fragmentos e os relatos são reconstruídos pelo toque do imaginário. Seja o caminho percorrido pelo avô, seja a cidade dos seus antepassados, o factual se imbui do poético:

Era a primeira face do espelho - a severa e sem risos- que meu avô assumia para ir de manhã, de sua casa para o trabalho. Não é difícil imaginar como ele faria esse caminho, se juntarmos à verdade o verossímil que não é senão um esqueleto da verdade encarnada pela poesia. ${ }^{19}$

É por ser neto do retrato que sou periodicamente atuado pela necessidade de ir a São Luiz do Maranhão. Essa sempre procrastinada viagem, se eu não a faço com o corpo, realizo em imaginação. Desde menino, quando, de tanto ouvir falar em Ceará e Maranhão, eu enchia cadernos e cadernos do desenho de navios inverossímeis, onde havia um exagero de âncoras pendentes, gáveas em cada metro de mastro, mastros sem conta e as chaminés deitando uma fumaceira de erupção vulcânica. ${ }^{20}$

Recuperando a expressão do seu avô ao sair de casa, rememorando nostalgicamente a cidade de São Luís do Maranhão, onde nasceram seus avós, o memorialista ligado à terra, aquele espaço, por uma força denominada por ele como genealógica, do clã, recupera os fragmentos desse passado pela imaginação. Essa mesma força, genealógica e imaginativa, o ajuda a reconstruir o mosaico da cozinha, do trabalho das mulheres, da sua tia-avó paterna - Dona Irifila. O tratamento ficcional, a interpelação imaginativa, o permite até mesmo recompor os personagens e sua capacidade de sentir gostos, cheiros como na cena do banquete oferecido pela senhora como uma estratégia para acabar com a seção de jogos do marido - o comendador Iclirérico Narbal Pamplona - em sua casa:

À hora da ceia, requintou-se. Nunca suas bandejas, seus bules e seus açucareiros de prata tinham tido tal polimento. Nunca tirara tanta toalha de renda das arcas e das cômodas perfumadas a capim-cheiroso. Nunca seus guardanapos de linho tinham recebido tanta goma. E que fartura. Chá. Chocolate, moscatéis, madeiras, portos. Os licores da França, da Hungria e os nacionais de piqui, tamarindo e

\footnotetext{
${ }^{19}$ NAVA. Baú de ossos: memórias, p. 67.

${ }^{20}$ NAVA. Baú de ossos: memórias, p. 22.
} 
jenipapo (...) E no meio da bandeja, a mais alta compoteira com o doce do dia aparecendo todo escuro e lustroso, através das facetas do cristal grosso, de um pardo saboroso como o de banana mole, de pasta de caju, do colchão de passas com ameixas pretas, do cascão da goiaba com rapadura. O comendador resplandescente destampou a compoteira: estava cheia até as bordas, de merda viva! (...) Não conheci o casal Iriclérico-Irifila, senão de ouvir dizer. Mas conheci pessoalmente suas filhas, umas santas. Conheci suas netas, umas santas. (...) A toda a descendência. Da Irifila ficou apenas a sombra no anedotário familiar. ${ }^{21}$

Em uma mescla de realidade e fantasia, os familiares, a cidade, tudo é descrito. Nos trechos a seguir, o factual é enlaçado pela ficção e personagens dos romances machadianos se misturam, relidos, junto às representações das pessoas, familiares das memórias de Pedro Nava o que deixa evidente o espaço da narrativa como interdiscursivo:

Esses caminhos que cortavam o centro urbano esse encontro vivo e característico das ruas das freguesias do Sacramento, Santa Rita e Candelária, cheio de teatros como o Alcazar da Uruguaiana, das redações dos jornais da mesma rua e da Gonçalves Dias, de prostíbulos como o Palácio de Cristal, do canto da última com Rosário. Neles passava meu avô, acotovelando-se com políticos, portugueses, escravos, marinheiros, barões, crioulas (...) desviando-se dos carris, das vitórias, gôndolas, tílburis (...) burros sem rabo que atropelavam desordenadamente o solo escorregadios das imundícies, das cascas de frutas, detritos alimentares, baganas, escarros e cusparadas, respirando o cheiro especial do velho centro do Rio de Janeiro - misto de exalações de frutas frescas e frutas podres, das bostas dos estábulos, dos moinhos de café, das barracas de peixe, dos montes de lixo, de leite azedo, de queijo ardido, dos mercados de flores, do perfume das mulheres que passavam rangendo sedas - machadianas Fidélias, Capitulinas e Vigílias! ${ }^{22}$

O registro concreto e objetivo do passado é reelaborado pela metamorfose da imaginação, trazendo um emaranhado de histórias e imagens que o narrador tenta reconstruir dramatizar criticamente no discurso do presente. O vivido é instrumento para o trabalho imaginário; seja pela memória voluntária, exercício consciente e seletivo no intercalar dos fragmentos memorialístico, seja pela memória involuntária, evadido por imagens fragmentos aleatórios que conduz o sujeito as essências violentamente a revelia, o narrador busca reconstruir o passado:

Uns fatos voltam ao sol da lembrança com a rapidez dos dias para os mundos de pequena órbita. Vivem na memória. Perto do astro-rei, como Vênus e Marte. Há os distantes, como Saturno. Outros, cometas, passam roçando e queimando; depois somem em trajetórias mergulhadas nas distâncias espaciais do

\footnotetext{
${ }^{21}$ NAVA. Baú de ossos: memórias, p. 30.

${ }^{22}$ NAVA. Baú de ossos: memórias, p. 58.
} 
esquecimento. Tocam, com suas caudas, galáxias perdidas na mais prodigiosa altura das alturas; voltam, novamente, ameaçando arrasar tudo com o rabo de fogo. ${ }^{23}$

Atento agudamente nesses retratos no esforço de penetrar as pessoas que conheci (uns bem, outros mal) e cujos pedaços reconheço e identifico em mim. Nas minhas, nas deles, nas nossas inferioridades e superioridades. Cada um compõe o Frankenstein hereditário com pedaços dos seus mortos. Cuidando dessa gente em cujo meio nasci e de quem recebi a carga que carrego (carga de pedra, de terra, lama, luz, vento, sonho, bem e mal) tenho que dizer a verdade, só a verdade, e se possível, toda a verdade. ${ }^{24}$

Se a batida do Ceará é uma rapadura diferente, a batida de minha avó Nanoca é para mim coisa à parte e funciona no meu sistema de paladar e evocação, talqualmente a madeleine da tante Leonie. Cheiro de mato, ar de chuva, ranger de porta, farfalhar de galhos ao vento noturno, chiar de resina na lenha dos fogões, gosto d'agua de moringa nova - todos têm a sua medeleine. (...) Para mim, roçar os dentes num pedaço de batida é como esfregar a lâmpada de Aladim - abrir os batentes do maravilhoso. Reintegro imediatamente a Rua Aristides Lobo, no Rio; a Direita, em Juiz de Fora; a Januária, em Belo Horizonte - onde chegavam do norte os caixotes mandados por Dona Nanoca com seus presentes para os netos. Docemente mastigo, enquanto uma longa fila de sombras vem dos cemitérios para tomar seu lugar ao sol das ruas à sombra das salas amigas: passam lá fora o Coronel Germano e Dona Adelina Corroti numa conversa de palavras sem som. ${ }^{25}$

Os trechos citados anteriormente evidenciam dois modos de interpelação da memória, do vivido, para a recriação poética. Trata-se do esforço restaurador da memória voluntária que por meio de analogias entre histórias do passado, documentos e retratos "voltam ao sol da lembrança com a rapidez dos dias” na busca por recompor o "Frankenstein hereditário”; e também da memória involuntária, ou seja, o resgate momentâneo de algo que parecia perdido, como a batida do Ceará, que emerge a consciência, “ameaçando arrasar tudo com o rabo de fogo”. Nesse último modo de recompor o passado, o poeta é evadido por imagens, sensações "milagrosas", simultâneas e uma visão totalizante, como nesta passagem:

Assim, quantas vezes e quantas vezes viajei, primeiro no espaço, depois no tempo, em minha busca, na de minha rua, na do meu sobrado...Custei a recuperá-lo (...) Foi preciso o milagre da memória involuntária. (...) Olhando as janelas apagadas. De repente uma acendeu e os vidros se iluminaram mostrando o desenho, trinta anos em mim adormecido. Acordou para me atingir em cheio, feito bala no peito, revelação (...) Essa luz prestigiosa e mágica fez renascer a

\footnotetext{
${ }^{23}$ NAVA. Baú de ossos: memórias, p. 244.

${ }^{24}$ NAVA. Baú de ossos: memórias, p. 211.

${ }^{25}$ NAVA. Baú de ossos: memórias, p. 35.
} 
casa do fundo da memória, do tempo, das distâncias das associações, da lembrança (...) Tudo, tudo, todos, todos se reencarnando num presente repentino, outra vez palpável, visível, magmático,coeso, espesso e concentrado. ${ }^{26}$

A escrita da memória, nesse artifício de resgate do tempo, “é interpelada pela imaginação, representada e relida através da linguagem, que enlaça imagens de um sujeito, que são dependentes de outras imagens como a de familiares e da sociedade que o abriga”. ${ }^{27}$ A narrativa traz uma linguagem aberta em que ressoam diversas vozes, as quais "resguardam precariamente os traços da história - seja aquela dos lugares que percorre, seja a sua própria história remanescente em fragmentos e episódios dispersos na memória”. ${ }^{28}$ Percebe-se, portanto que o centro da obra é constantemente deslocado e as imagens do sujeito aparecem sempre simultâneas a outras figuras como a dos familiares e da própria sociedade.

Em Baú de ossos, a heterogeneidade dos textos documentais, relatos e as reverberações imaginárias do narrador são apresentados em fragmentos entrecortados pictoriamente em uma perspectiva relacional. A narrativa configura-se por uma volubilidade de imagens, representações do eu - sujeito das memórias - e do mundo em um processo de ramificações e desdobramentos analógicos.

\section{IMAGENS EU-MUNDO: A DINÂMICA DAS REPRESENTAÇÕES NO BAÚ DE OSSOS}

No fundo, bem no fundo, o Brasil para nós é uma expressão administrativa. O próprio resto de Minas, uma convenção geográfica. O Triângulo, já não quis se desprender e juntar-se a São Paulo. Que se desprendesse. (...) Tudo o que quiserem, porque a terra em que andamos puxados pelos pés, querendo deitar raízes, homens árvores como o mito de Dafne é a das serras em formas das chaminés, cabeças, barbacãs, lanças, seios, anátemas, agulhas, cidades, manoplas (...) Serras, serras, picos... Curral, Rola-Moça, Piedade, Soledade, Caraça (...). Serras de cujas encostas descem os rios que vão ao São Francisco e ao Paraíba para soltar no Atlântico o nosso sangue mineral. (...) Rios que levam até o mar o sabor de Belo Horizonte, Sabará, Caeté, Mariana, Ouro Preto (...). Rios que pela vida subterrânea dos lençóis d'agua do solo das igrejas e da terra dos cemitérios a substância calcárea de meus parentes (...). Essas áreas, eu não posso chamar de pátria, porque não as amo civicamente. O meu sentimento é mais inevitável, mais profundo e mais alto porque vem da inseparabilidade, do entranhamento, da unidade e da consubstanciação. Sobretudo, da poesia (...). Essa é a minha terra. Também ela me tem e a ela pertenço sem possibilidade de

\footnotetext{
${ }^{26}$ NAVA. Baú de ossos: memórias, p. 301-302.

${ }^{27}$ BOSI. Memória e sociedade: lembrança de velhos, p. 17.

${ }^{28}$ GUIMARAES. Imagens da memória: entre o legível e o visível, p. 153.
} 
alforria. Do seu solo, eu como. Da sua água, bebo. Por ela, serei comido. Esta é simplesmente a terra de nascimento, vida, paixão e morte do mineiro. Terra de Luís da Cunha. Esse Luís Cunha é meu bisavô, pai da minha avó materna. ${ }^{29}$

O trecho de Baú de ossos explicitado acima evidencia fortemente como que as representações do sujeito são constituídas e perpassadas pela genealogia familiar, sobretudo pelo espaço social. "O resgate da memória individual torna-se múltiplo, pois é perpassado por outras memórias da coletividade. ${ }^{30} \mathrm{O}$ narrador no fio de suas memórias segue inúmeros caminhos que entrecruzam imagens e representações de si e do mundo em um processo de articulação, convergência justapositiva. Através de uma lei de atração das imagens, a prosa memorialística desenha, pela linguagem, encadeamentos analógicos a sugerir uma variedade imagística, bem como uma gama de significâncias, representações. Parafraseando Barthes, o texto, a obra de Nava, é um incontornável parasita das imagens. ${ }^{31}$

A imagem como essência da analogia é a técnica que as Memórias utilizam para representar o sujeito e sua autobiografia e dimensioná-la para um espaço mais amplo como a história de grupos e uma visão da sociedade. Os nexos da prosa estão na articulação da representação do sujeito, de seus familiares e do próprio país - imagens que partem do universo particular para um todo universal. Por meio de enumerações, essas imagens são concatenadas na narrativa a percorrer uma trajetória que parte da intimidade do narrador, de sua particularidade, para alcançar um telos de imagens múltiplas e generalizadas.

O fragmento seguinte evidencia esse processo através da representação da figura do presidente Antônio Carlos. Nele, o narrador expõe primeiramente a imagem particular, a do clã familiar, e logo parte para esferas maiores que possibilita alcançar uma visão da sociedade:

O Dr. Antonio Carlos Ribeiro de Andrada era filho de pai homônimo e de Dona Adelaide Lima Duarte, descendente de Aires Gomes. Não tinha nada dos rompantes paulistas dos Andradas, mas era cheio de ronha mineira dos Lima Duarte. Tinha dos primeiros, o físico e o nome dos segundos, a astúcia e aquilo que Mario de Andrade chamava o "cauteloso pouco a pouco". E mais a simpatia e aquele encantamento que ele dividia com outros Lima Duarte - os seus primos Penido. Por estes ele se ligava aos Burnier, Monteiros, Teixeira Leite, Assis, Álvares da Silva (primeira ponte para o Oeste e para a gente do Pompeu), Ribeiros, Ribeiros de Oliveira; Batistas de Oliveira, Nunes Limas, Badarós,

\footnotetext{
${ }^{29}$ NAVA. Baú de ossos: memórias, p. 110-111.

${ }^{30}$ BOSI. Memória e sociedade: lembrança de velhos, p. 335.

${ }^{31}$ BARTHES. O óbvio e o obtuso, p. 21.
} 


\begin{abstract}
Mascarenhas, Vidais Barbosa Lage e Valadares (segunda ponte para o Oeste e para a gente do Pompeu). Pelo mano José Bonifácio, aos Lafayettes e aos Stocklers. Pela esposa, aos Olindas, Araújo Lima, Guimarães, Azevedos, Moreiras e Régis de Oliveira. Tudo isso representava uma família extremamente solidária e estendendo-se, em distância, da Borda do Campo a Petrópolis, passando por Juiz de Fora e zona mesopotâmica de Minas. / Acresce que, além de solidária, essa gente era a possuidora. Das fazendas, das companhias, das empresas, das indústrias, das fábricas, do prestígio das profissões liberais, das santas-casas, das confrarias, das obras pias, das gotas de leite, das sopas dos pobres, das irmandades e dos apostolados. Uma piedade exemplar fazia chover sobre todas as bênçãos da Igreja e os juros das apólices. / Deste modo, tocar num só era por en branle e a favor, o Executivo, o Legislativo, o Judiciário, os correligionários, os compadres, os primos de primos dos primos, os contraparentes, Guy de Fongaland, Santa Teresinha do Menino Jesus, o próprio Menino Jesus, Nossa Senhora do Perpétuo Socorro, a dos Navegantes, a dos Aflitos, a de Lurdes, o Padre, o Filho e o Espírito Santo... Desses degraus - não precisava esforço para dominar politicamente. ${ }^{32}$
\end{abstract}

Pode-se perceber que a figuração do sujeito é justaposta à relação familiar; uma inserção do indivíduo no clã. Além disso, representa-se esse clã e sua relação com a sociedade. O diálogo entre as imagens que representam o personagem, sua família e a sociedade é explicitado nas palavras do narrador, poucas linhas acima do trecho escolhido: "Ninguém pode compreender nada da história social de Minas, se não entender um pouco de genealogia para estudar os troncos e os colaterais.”33 Dessa maneira, apresenta-se na reconstituição do sujeito e do seu passado, a variedade de relações com outras imagens genealógicas e sociais. Trata-se na análise do crítico Antonio Candido de uma "estilística da universalização", a qual possibilita a representação da imagem do indivíduo e também sua relação com o mundo, por virtude de uma técnica enumerativa que cria novas ramificações imagéticas a partir de elementos iniciais. ${ }^{34}$

No ensaio “A poesia do reesvasiado: imagens da nação no memorialismo mineiro”, Wander Melo Miranda ${ }^{35}$ analisa essa relação justapositiva de imagens autobiográfica, biográfica e social, sob a perspectiva da poética do reesvasiado, como denomina. A partir do princípio de despeçagem e de colagem, os livros de Nava são apresentados como uma maneira de intervenção performativa no âmbito da representação do nacional. Nesse sentido, Baú de Ossos é visto como um jogo de discursos, de experiência do signo, cuja função é desregular o tempo autogerador da

\footnotetext{
${ }^{32}$ NAVA. Baú de ossos: memórias, p. 282-83.

${ }^{33}$ NAVA. Baú de ossos: memórias, p. 282.

${ }^{34}$ CANDIDO. Poesia e ficção na autobiografia[0], p. 65.

${ }^{35}$ MIRANDA citado por CANÇADO. Memórias videntes do Brasil: a obra de Pedro Nava, p. 14.
} 
nação a ponto de reduzi-lo aos rastros da experiência social ou individual rememorada. O mundo brasileiro é recriado pela linguagem em uma operação crítica, num plano pictórico em que se traça o perfil do sujeito e da sua família. Assim, “quem toca as memórias de Pedro Nava, toca ao mesmo tempo uma certa fisionomia do Brasil, um aspecto ou conjunto de aspectos da nossa formação e da nossa história social” ${ }^{36}$ Os trechos que seguem explicitam ainda melhor como a descrição das memórias, do sujeito, é perpassada pela própria cartografia do espaço social de Juiz de Fora, sua cidade de origem:

Eu sou um pobre homem do Caminho Novo das Minas dos Matos Gerais. Se não exatamente da picada de Garcia Rodrigues, ao menos da variante aberta do velho Halfeld e que, na sua travessia pelo arraial do Paraíbuna, tomou o nome da rua Principal e ficou sendo depois a rua Direita de Juiz de Fora. Nasci nessa rua, no número 179, em frente à Mecânica, no sobrado onde reinava minha avó materna. E nas duas direções apontadas por essa, que hoje é a Avenida Rio Branco, hesitou minha vida. ${ }^{37}$

A rua Halfeld desce como um rio, do moro do Imperador e vai desaguar na Praça da estação. Entre sua margem direita e o Alto dos Passos estão a Câmara, o Fórum, a academia de Comércio com seus padres, o Stella Matutina com suas freiras, a Matriz com suas irmandades, a Santa casa de Misericórdia com seus provedores, a Cadeia, com seus presos (testemunhas de Deus - contraste das virtudes do Justo) - toda uma estrutura social bem-pensante e cafardenta que se pudesse amordaçar a vida e suprimir o sexo, não ficaria satisfeita e a trataria ainda, como na frase de Rui Barbosa, de forrar de lã o espaço e caiar a natureza de ocre. $^{38}$

Através da volúpia de um sujeito por recompor seu passado, restabelecer a sua imagem, as imagens da sociedade aparecem matizadas em um trabalho poético de recriação. A representação das memórias revela "no médium do espírito subjetivo que se volta sobre si mesmo, os sedimentos da relação histórica do sujeito com a objetividade, do indivíduo com a sociedade”. 39

Por meio da linguagem, configura-se tanto a substancialidade da representação das memórias individuais quanto fazem aflorar representações coletivas, ultrapassando assim a mera individualidade autobiográfica:

\footnotetext{
${ }^{36}$ MIRANDA citado por CANÇADO. Memórias videntes do Brasil: a obra de Pedro Nava, p. 14.

${ }^{37}$ NAVA. Baú de ossos: memórias, p. 13.

${ }^{38}$ NAVA. Baú de ossos: memórias, p. 14.

${ }^{39}$ ADORNO. Notas de literatura I, p. 72.
} 
O projeto de Nava implícito nas memórias é, portanto, de uma narrativa enorme, de uma narrativa épica capaz de documentar o vasto conteúdo da formação social brasileira, já que a história que nos conta vai ganhando a dimensão simbólica do geral à medida que cresce e permite reconhecer cada vez melhor a imagem do destino singular de um individuo - de um pobre homem, só compreensível pelas relações particulares múltiplas e complexas que mantém com um mundo ainda mais vasto, que é o seu e até certo ponto o de todos nós. ${ }^{40}$

Desta maneira, em face da articulação de imagens - do sujeito, de sua família e da sociedade brasileira - na narrativa, renomados críticos aproximam o discurso de Baú de ossos a uma tradição memorialística diferenciada, a qual se fundamenta na relação entre a imaginação ficcional do passado histórico brasileiro ao passado biográfico do memorialista. O discurso de Nava é constantemente equiparado a livros como Casa-grande \& senzala, do sociólogo Gilberto Freyre, o qual, por meio da releitura de documentos de cunho científico, que dissertam sobre a sociedade e cultura nordestina latifundiária dos anos 1600 a 1800, busca, por um olhar individuado, antropológico, reconstruir a imagem histórico-social do país revestida sobre a história íntima do autor. Nava, ainda que não buscasse, ao contrário de Gilberto Freyre, devassar a cultura brasileira no relato de sua genealogia, acaba por fazê-lo na medida em que explora seu passado representando não só a si e seus familiares, mas toda sociedade, ou seja, traz imbuído à representação autobiográfica a representação histórico-social do país. Nesse sentido, confirma-se o estatuto híbrido das memórias, sobretudo desse livro inicial, Baú de ossos, o qual tem como objeto a representação imagética do - eu e o mundo - configurados em uma forma específica de discurso literário, em um método de composição que converge gêneros e linguagens, prosa de ficção e historiografia.

\begin{abstract}
This paper aims the study of imagetic dimension in Baú de ossos. We seek to verify how subject, his family and Brazilian society images are constructed in narrative. Thereby, we look for noticing the transfiguration of these instances by imagetic reading possibilities, which relate analogically the subject and the world.
\end{abstract}

\footnotetext{
${ }^{40}$ ARIGUCCI JR. Enigma e comentário: ensaios sobre literatura e experiência, p. 76.
} 


\section{KEYWORDS}

Memory, image, Baú de ossos

\section{REFERÊNCIAS}

ADORNO, Theodor W. Notas de literatura I. Trad. Jorge de Almeida. São Paulo: Duas Cidades; Ed. 34, 2003.

ARIGUCCI JR, Davi. Enigma e comentário: ensaios sobre literatura e experiência. São Paulo: Companhia das Letras, 1987.

ARRIGUCCI Jr., Davi. Humildade, paixão e morte: a poesia de Manuel Bandeira. São Paulo, Companhia das Letras, 2003.

BARTHES, Roland. O óbvio e o obtuso. Trad. Isabel Pascoal. Lisboa: Ed. 70, 1984.

BENJAMIN, Walter. Magia e técnica, arte e política: ensaios sobre literatura e história da cultura. 7. ed. Trad. Sérgio Paulo Rouanet. São Paulo: Brasiliense, 1994.

BOSI, Ecléa. Memória e sociedade: lembrança de velhos. São Paulo: T.A.Q Editor, 1983.

CANDIDO, Antonio. Poesia e ficção na autobiografia. In: . (Org.). A educação pela noite \& outros ensaios. 5. ed. Rio de Janeiro: Ouro sobre Azul, 2006. p. 51-69.

CANÇADO, José Maria. Memórias videntes do Brasil: a obra de Pedro Nava. Belo Horizonte: Ed. UFMG, 2003.

DIDI-HUBERMAN, Georges. O que vemos, o que nos olha. Trad. Paulo Neves. São Paulo: Editora 34, 1998.

HUTCHEON, Linda. Poéticas do pós-modernismo: história, teoria, ficção. Trad. Ricardo Cruz. Rio de Janeiro: Imago, 1991.

LE GOFF, Jacques. História e memória. Trad. Bernardo Leitão et al. 2. ed. Campinas: Ed. Unicamp, 1992.

GUIMARAES, César. Imagens da memória: entre o legível e o visível. Belo Horizonte: Ed. UFMG, 1997

MIRANDA, Wander Melo. Imagens de reesvasiado: imagens da nação no memorialismomineiro. Cadernos da Escola do Legislativo, Belo Horizonte, n. 2, v. 4, jul-dez. 1995.

NAVA, Pedro. Baú de ossos: memórias. Rio de Janeiro: J. Olympio, 1974.

SOUZA, Eneida Maria de. Pedro Nava. Rio de Janeiro: Agir, 2005. 